\title{
Designing Wayang Kulit Purwa with Gatotkaca as the Character in Game
}

\author{
Nunnun Bonafix \\ School of Design \\ Bina Nusantara University \\ Jakarta, Indonesia \\ nbonafix@binus.edu
}

\begin{abstract}
Young generation nowadays has lack of knowledge on the culture of shadow puppet (wayang kulit) which is a heritage that has a high value of art and philosophy. This is caused by the impact of foreign cultures rapidly entering Indonesia. The rapid development of the information technology through internet \& game has led to globalization that seems to be not limited to space and time. The speed of information and foreign cultures cannot be stopped. The culture of shadow puppet (wayang kulit) is getting eroded and is not much known by the modern society nowadays. This is an irony to a big nation which has a rich heritage, so it is our obligation as a citizen to maintain and preserve it. Based on the formulae of AIGA 2015 that defines (time + content + context) $/$ time $=$ experience design, the game of wayang kulit (shadow puppet) Gatotkaca put forbattled different experience to users in exploring the information and entertainment in those media. Having the spirit of moderate Postmodernism, the design plan called User Interface which combines the modern and classic traditional elements will encourage new experience to the users (Experience Design). The design recognizes times and trends, and it keeps changing as the development of the times. The design can be a pace setter to next individuals who are called to maintain and preserve national cultures, in general, and wayang kulit purwa, in particular, through digital media. The development in the modern era will not change the identity of shadow puppet (wayang kulit) culture since it has solid foundation.
\end{abstract}

Keywords-puppet, experience design, gatotkaca, postmodernism, digital Media

\section{INTRODUCTION}

Indonesian is known as a country that is rich of its cultures and has complex societies who live in many regions in Indonesia. Each has various traditions and cultures. Among many cultures, there is the art of wayang (puppet) and pendalangan (puppetry) that lasts from time to time.

Wayang kulit (shadow puppet) is a traditional art that develops especially in Java Island. The word wayang comes from "Ma Hyang" which means spirit, gods or Almighty God. Generally, wayang plays are taken from Mahabarata and Ramayana scripts. Wayang is acknowledged as a masterpiece since wayang has a high value in human civilization. Wayang is full of values that are reflected in characters, stories and various supporting elements.
The art of wayang (puppet) and puppetry is unique and sophisticated since its performance can be combined harmoniously with various arts such as performing arts, singing art, literary arts, fine arts and others. Wayang presents in its intact shape in aesthetics, ethics and philosophy. The art presentation in wayang show also contains various messages. Ethic message refers to the formation of nobility or akhlaqul karimah. Wayang is not only a show but also contains guidance. Javanese people even say "wewayangane ngaurip", the shadow of human life; from birth until death.

From the point of view of popular culture, the art of wayang kulit (shadow puppet) has a bigger opportunity to be developed in a creative industry rather that when this art is perceived from the perspective of tradition. A big breakthrough is required. One way is being produced as a digital technology based culture industry like website so that the basic concept of wayang kulit performing art as a tradisional media can survive. By digitalization, wayang kulit art performing is easier to be absorbed and consumed by anyone interested in. There is no limit in age, gender and sosial status.

The reason why game media is selected is the fact that smartphones and Internet are so popular. Moreover, they have become a lifestyle and the need of society today. Wayang kulit purwa content is not only transferred from television media and printed books into games but also packaged uniquely, interestingly and interactively. The characters in wayang kulit of Central Java are categorized into its presence into the story, class and explanation of the characters. The users can obtain multimedia information about wayang kulit in non-linear way, since the navigations prepared bring enjoyable experience for users.

There have been previous studies about wayang kulit in digital multimedia. However, this study was aimed to design a website and game presenting wayang kulit purwa content and also present thorough explanation on the correlation on modernity influence and the progress of time towards Indonesian people with tradisional culture like wayang kulit.

\section{RESEARCH METHOD}

The research methods conducted in discussing this journal are: 


\section{Literature Study}

This method is conducted by finding or probing information or knowledge related to scientific sources such as books, journals and others.

\section{Observation}

This method is done by browsing in Internet about design phenomenon and game based technology, as well as a preferred game and which game becomes a trend among the teenagers in the city nowadays.

\section{Interview}

Interview conducted by the researcher in this study is unstructured interview. The interview is used to gather information that cannot be obtained by observation. By having an interview, the researcher is able to obtain thorough information related to wayang kulit purwa. The resource person is Bapak Ekotjipto, SH acting as the chief of Pepadi and Bapak Sumari from Sena Wangi (Sekretariat Nasional Pewayangan Indonesia- National Secretariat of Indonesian Shadow Play).

\section{Documentation}

This method is done by collecting information of pewayangan (shadow puppet) activities in the forms of photographs and videos.

\section{Result AND ANALYSIS}

\section{Game Media}

In modern times the art world again must face new challenges as a result of the technological revolution. The problem that arises is how to integrate technology systems into current trends into the shadow puppet show. But when the time of emerging technology and globalization in line with the current puppet show is now also able to evolve according to the times itself. In a puppet show artists are now able to adapt by including elements of the technology into the show.

Before Asep Sunandar "Cepot" Sunarya create a character, a puppet show less desirable, especially young people. Puppet show only interested only parents. Figure of Cepot show with jokes and criticism-criticism is typical Sundanese people. Puppet is its lower jaw can wiggle when speaking, can also stretch the bow and release the arrow, without the aid of a hand puppeteer. Even Prof. Tjetjep Rohendi Rohidi, M.A said in a workshop on "Development of Poor Urban Communities" that the "People of the puppet show created by Asep Sunandar Cepot Sunarya be quickly accepted by the public although not in accordance grip puppets, because the help of technology. Selection of a simple game media to showcase leather puppet Purwa based on survey data from APJII that online game players active in Indonesia is 6 million or approximately $10 \%$ of the number of internet users in Indonesia. This estimate is derived from the data of Facebook users in Indonesia that has broken over 30 million people, of which $50 \%$ of users never played a game online that is contained in these social networking sites.

\section{Puppet Characters Purwa}

In the puppet story, puppet characters are divided into two "groups". One is the puppet characters good temper, and the other is the figures puppet with bad tempers. Puppet characters who are members of the Pandavas is a representation of goodness, while the Kauravas is the symbol of evil. Published main character puppet prototype which is representation of goodness.

Puppet figures purwa widely known by the people of Indonesia. Five Pandavas is one of them, is the designation of five brothers, sons of Pandu Dewanata that Yudhisthira, Bhima, Arjuna, Nakula and Sadewa. As well as the son of Bima is Ghatotkacha.

For that use a random method (random sampling) to determine the character purwa main puppet in this design thesis. Meaning of random (random sampling) is any member of the population has the same chance and opportunity to be selected as a sample [1].

\section{Puppet Ghatotkacha in Various Versions of Digital}

Based on the observations that have been made, it is clear that the visual appearance of the play Ghatotkacha already created many versions through digital media. From the start of re-planning Ghatotkacha character, incorporating elements of anime on Ghatotkacha to play 3-D games and advanced visual detail on the play Ghatotkacha. It becomes an idea that plays Ghatotkacha been visualized according to modern tastes are becoming a trend nowadays.

In Game puppet, made IGEM team. Showing games puppet genre Platformer like Mario Bros Nintendo era in the 90s. The game pretty well designed and detailed, but visually less explored side.

This is in accordance with the said Mr. Ekotjipto, SH, chairman of the Association Indonesian puppetry (Pepadi) that there is order in the puppet also called grip. However, creativity puppet show opened wide as possible as long as it does not ransacked the original story and contains a moral message. "The hope puppets according to the times are always dynamic, not static. That is as good as any incoming foreign cultures, especially in the younger generation, the puppet will not lose with the technological advances of the incoming foreign art. We need to develop a continuous puppet, "said Sumardi, Chairman of the Organizing Committee Puppet Festival Indonesia (FWI), 2014.

That the art of puppet purwa viewed from the perspective of popular culture, it has the opportunity to be developed into a creative industry. With the digitization of art puppet show will continue to grow be creative industry more easily consumed by the modern time. The challenge for the creators of art and technology in creating product of the nation who can be consumed by people of national and international, and no less important is to increase appreciation people's culture purwa puppet itself. 


\section{Pre Game Design}

As envisioned by the AIGA of trends in 2015 which mentions a designer obligation to understand the form and content are conditioned by context and its influence on the present. That spawned something called "Experience Design" [2].

Experience Design is a discipline created by the reality of today's communication, simple, with no contact with each other from beginning to end, but a means. Experience Design, as a discipline, it involves a lot of capabilities associated in the past with many different professions. In this case, it is an example of a team orientation, cross-disciplinary challenges in today's economy. Experience Design becomes meaningful to the type that has a characteristic Experiences The young, enthusiastic, self-expression as well as the consumer becomes a major segmentation. Experiencers have a character who likes to spend money, are interested in new things, entertainment, fashion, socializing and luxurious look. Looking at the trend in 2015 that proclaimed AIGA emphasized more contemporary factors, postmodernism has become the spirit of the design of "The play Wayang Kulit Purwa Ghatotkacha Raised in The Game".

\section{Sketch Beginning Visual \& Game Storytelling}

In designing the game, the concept is taken from the story of one of the round Ghatotkacha birth. Here the story is by Guru, Ghatotkacha given three gifts. The first gift is Kotang Antakusuma makes Ghatotkacha can fly quickly. The second is called the gift of Caping Basunanda cap, which has a magic power when in contact with heat will not feel the heat. And if the rain does not become wet. The gift of a third, of shoes In Kacarma who have supernatural powers will not be affected from somewhere. Games created with the Platformer genre, where Ghatotkacha will meet with Batara Guru above. In the game Ghatotkacha make the trip up, but had to face obstacles. Good spirits are also animals. After Ghatotkacha met Batara Guru then Ghatotkacha will receive a prize which is the third incarnation of the gift that is Kotang Antakusuma, Caping Basunanda and Pada Kacarma.

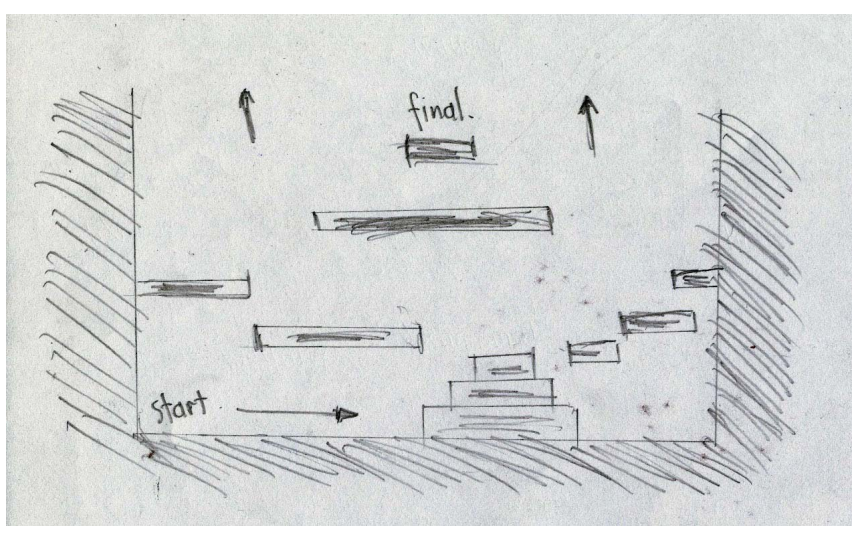

Fig. 1. Game Sketch
Expected each user gets a different experience when viewed from the side of the story concept tailored to Ghatotkacha story, the visual and design in the puppet play in the game. In the hierarchy of visual display that emphasizes traditional Ghatotkacha Game, then the user will see the visual

display is prominent, sturdy and complex. Ornamental motifs that appear very obtrusive and also other elements.

The main target of the user games actually are among young people ages 10-30 years. The question is whether it is appropriate to its target audience? The spirit of postmodernism in the process of game design puppets. Mark Ledbury's statement (2006) Postmodernism is a movement against hierarchy and performativitias. At least in the design later, there is a spirit not to round up the hierarchy.

As I've said [3] that the main point of Post Modernism is Cyber, Virtual and Digital. Looked in the mapping above that appeared a few keywords that refer to points Cyber, Virtual and Digital such as Internet, Computers, Digital Media.

\section{Game Design Process}

In the process of game design, divided into several main stages, namely:

- User Experience Design + User Interface based on a preliminary sketch

- Design content such as text, image, audio, story along with the game level

- Design Coding Programming in the game in the form of Actionscript

- Game testing

The Game

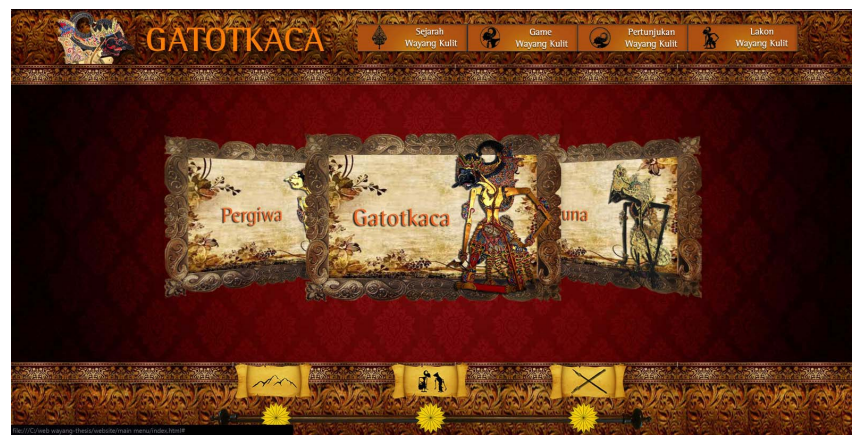

Fig 2. Main Menu

Visual design of Ghatotkacha game is still rely on the traditional elements like there are two kinds of clouds; mega cloudy and regular clouds. Here combined two clouds as a backdrop. Awan used to say as by Ghatotkacha walk somewhere or road at a certain height. Also placed a mountain that looked vaguely as part of the natural beauty alone. Altitude, clouds and mountains have a strong enough 
correlation with Ghatotkacha story taken as a story concept game at a level that has been designed.

On roads that must be passed Ghatotkacha by walking left and right and jump, given grass to add to the scenic beauty is also to include elements of trees with different types. Here the user will feel a different experience than the puppet game. Shades of brown viscous coupled elements bricks and rocks increasingly pamper the user to keep the traditional feel though different impression than a puppet show prototype.

Concept 2 dimension to the game as well to maintain the originality views of wayang kulit even placed on digital media. Coupled models that adopt the platformer genre game from one of the best-selling game of all time, namely Mario Bros. Mario character has appeared 200 game titles and has sold 193 million copies worldwide. This is the background writer puppet design games with the genre. Ghatotkacha displayed with Mario Bros style famous in the world.

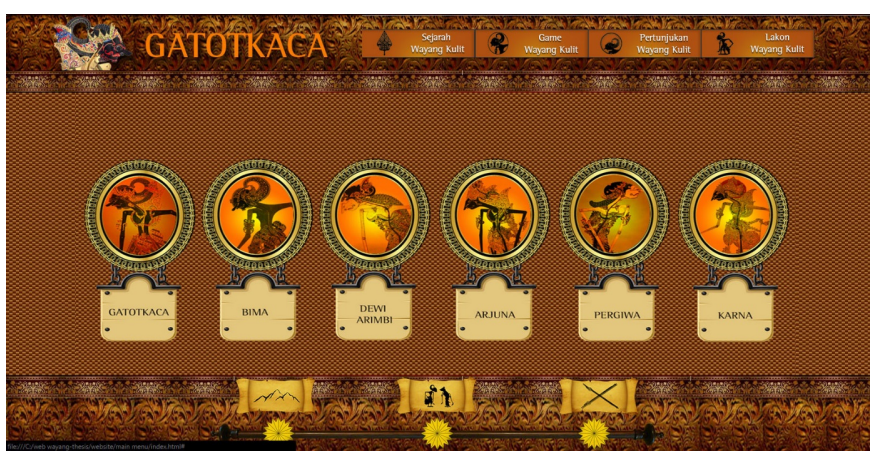

Fig 3. Game Figure

Ghatotkacha trip to meet the god Batara Guru, will be hampered and hindered by the spirits and animals. Users will use a strategy of his own choice and Ghatotkacha going all out to use his strength to fight it all.

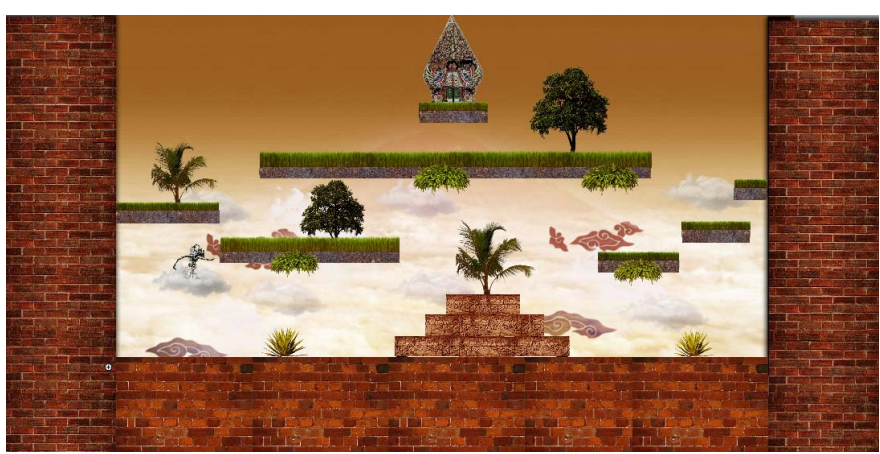

Fig 4. The Game Model

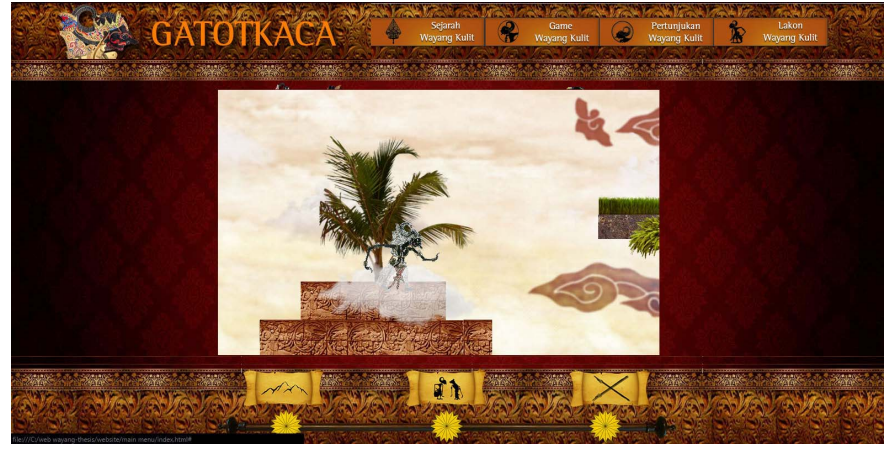

Fig 5. The Game Model(2)

\section{CONCLUSION}

The present demands of the user will be a new experience in operating multimedia is a necessity. The designers today is no longer focused on the User Interface, but already have to enter a higher level that is interdisciplinary because of the demands of time. AIGA corresponding trend in 2015 that $($ time + content + context $) /$ time $=$ experience design

Answer the problems in the design of the play is Wayang Kulit Purwa Ghatotkacha Raised In The Game in glasses Experience Design can be concluded that the design of the past that did not even touch the needs of User Experience. Users simply regarded as a mere object that just enjoy the visual User Interface charming. Experience Design and User Experience which includes a Postmodernism. Postmodernism know their time. Multimedia works when viewed in the thinking of User Experience will continue to adapt to the changing times according to the demands of modern society are increasingly critical.

Game is a universal media (Modernism), but media content design of puppets in a game that postmodernism give the impression today that strong but not abandon the traditional elements will always intrigued the experiences group. Web and games are part of postmodernism, which focuses on virtual and digital.

\section{REFERENCES}

[1] W.Lawrence Neuman, Social research methods: Qualitative and quantitative approach., USA:University of Wisconsin, 2006, pp. 45.

[2] AIGA 2000, Insight: Defining the studio of 2015, 27 Februari, 2013.

[3] Ali, Matius, Estetika pengantar filsafat seni, Sanggar Luxor, 2011 pp. 123.

[4] Tim Penulis SENA WANGI, Ensiklopedi wayang Indonesia jilid 1, SENA WANGI, 1999, pp. 85.

[5] Tim Penulis SENA WANGI., Ensiklopedi wayang Indonesia jilid 2, SENA WANGI, 1999, pp. 60.

[6] AIGA 2000, (Form+content + context $)$ Time $=$ Experience design, Volume 1, number 1, 2000. 